\title{
A Dynamic Energy Budget (DEB) growth model for Pacific oyster larvae, Crassostrea gigas
}

\author{
B. Rico-Villa ${ }^{a}$, I. Bernard ${ }^{a}$, R. Robert ${ }^{a,}{ }^{*}$, S. Pouvreau ${ }^{a}$
}

\author{
a Ifremer, Département de Physiologie Fonctionnelle des Organismes Marins, Station Expérimentale d'Argenton, \\ Presqu'île du Vivier, 29840 Argenton, France \\ *: Corresponding author : R. Robert, Tel.: + 332 98895105; fax: + 33 298895777, email address : \\ $\underline{\text { Rene.Robert@ifremer.fr }}$
}

\begin{abstract}
:
Dynamic Energy Budget (DEB) theory aims to quantify the energetic framework of an individual organism as a dynamic model, from the uptake of food to its utilisation in metabolic processes (maintenance, growth, development and reproduction). The purpose of the present paper is to extend the existing DEB model for adult Pacific oyster Crassostrea gigas to the larval life stage of this species. We present the application of generic DEB theory to oyster larvae, with the formulation of the specific assumptions based on the characteristics of this stage. The model depends on seawater temperature and food density, as forcing variables, followed throughout the whole larval development. We calculated DEB parameter values for larvae by means of laboratory experiments specifically designed to collect datasets on ingestion and growth at different levels of phytoplankton density and temperature. The DEB model developed here showed good growth simulations and provided an extensive description of the energetic needs of $C$. gigas during its larval stage. It was demonstrated that, at $27^{\circ} \mathrm{C}$, a food density of $1400 \mu \mathrm{m}^{3} \mu \mathrm{I}^{-1}$ must be maintained throughout larval development to maximise growth and metamorphosis success. Timing of metamorphosis decreases exponentially with increasing temperature.
\end{abstract}

Keywords: Dynamic Energy Budget; Crassostrea gigas; Bivalve larvae; Ecophysiology; Growth 


\section{Introduction}

Bivalve molluscs (e.g. oysters, mussels, clams and scallops) represent a significant proportion of world aquaculture production (Helm et al., 2004), in which the most important commercial marine bivalve is the Pacific oyster, Crassostrea gigas (FAO, 2008). Traditionally, bivalve culture in France relies on the collection of juveniles from the natural environment but, due to irregular recruitment (spatfall) and the high demand for triploid oysters, spat production in hatcheries has been increasing rapidly over the last five years. In this context, a better understanding of the biology of $C$. gigas larvae is required because the larval stage is critical for hatchery management.

The growth and survival of bivalve larvae is determined by complex interactions between their physiology and the environmental conditions. Among the diversity of influencing factors, temperature and food concentration are considered to be the primary environmental factors affecting physiological processes in oyster larvae (Robert et al., 1988; His et al., 1989; Lemos et al, 1994; Dove and O'Connor, 2007). Quantitative study of the effects of these environmental factors and their interactions on larval growth can be aided by numerical models. An existing model for C. virginica larvae (Dekshenieks et al., 1993) explains growth and development as function of temperature, food concentration, salinity and turbidity. Nevertheless, this work does not examine the energetic functioning of larvae at the level of basic physiology (ingestion and maintenance processes). In C. gigas, a net production-type model (Bochenek et al., 2001; Powell et al., 2002; Hofmann et al., 2004) was developed to examine the biochemical influence of changes in food quality and quantity on larval development. Although this approach is more appropriate for modelling larval growth, this model lacks valid experimental measurements made for the whole larval development over a wide range of environmental factors. In addition, this model is based on the Scope for Growth concept (Bayne, 1976), which is empirically-based and free-formulated through allometric relationships (Bourles et al., 2009) and assumes that assimilated energy is immediately available for maintenance while the rest is converted into structural components (growth) or storage material (reserves) (Bochenek et al., 2001).

In the present paper, a more mechanistic energetic model is proposed based on the Dynamic Energy Budget (DEB) theory (Kooijman, 2000). The recent development of DEB theory offers a general framework for examining the bioenergetics of an organism in a systematic way. This theory describes the rates at which an individual organism assimilates energy from food uptake and stores this energy as reserves for allocation to the physiological functions of maintenance, growth, development and reproduction. In addition, DEB theory offers attractive improvements for energetic modelling based on simple assumptions that describe energy flow according to physiological processes that species have in common. This generic aspect allows different species to be compared, as the only interspecies difference will lie in the DEB parameter values. Most parameters can be estimated in the laboratory under controlled environmental conditions, using temperature and food density as forcing variables. Recently, practical applications of DEB theory have been validated for bioenergetics in $C$. gigas adults in natural surroundings (Bacher and Gangnery, 2006; Ren and Schiel, 2008) as well as in controlled conditions (Pouvreau et al., 2006; Bourles et al., 2009). Based on this last existing DEB model, the present study aimed to apply DEB theory to simulate growth of $C$. gigas at larval stage in the hatchery. This is the first model that would be capable of representing the energetic needs of a bivalve species throughout the whole larval life cycle. Furthermore, such model can be used to treat on a hierarchical basis the key parameters of Crassostrea gigas larval development and physiology, improve accordingly culture conditions in hatchery (e.g. metamorphosis delay) or knowledge of ecological requirements in surroundings (e.g. wild spat collection).

The first part of this paper presents some basic concepts of the DEB theory and assumptions made for $C$. gigas larvae. The second part consists of the estimation of DEB parameter values for oyster larvae from experimental data on ingestion and growth collected under precisely controlled conditions of phytoplankton density and temperature. The final part of the 
paper focuses on calibration and simulation with the larval DEB model using our own experimental datasets, and its validation based on the input of "external" data collected in our experimental facilities by means of other independent trials.

\section{Materials and methods}

\subsection{Concepts and DEB model formulation for the larval stage}

In DEB theory, an organism is partitioned into three main body components: 1) structural biovolume or somatic tissue; 2) stored energy reserve; and 3) gonads and/or stored energy reserves allocated to maturity and reproduction (Kooijman, 2000). Moreover, in the theory, three life stages are distinguished: 1) embryos, which neither feed nor reproduce; 2) juveniles, which feed but do not reproduce; and 3) adults which both feed and reproduce. DEB theory describes a larva as a juvenile because larvae feed and their resources are not yet allocated to reproduction, but to other developmental processes. Therefore, energy from food is stored directly as reserves and is then directed towards growth, development and their maintenance. The DEB model was accordingly simplified for the larval stage, compared with the adult stage (Pouvreau et al., 2006), due to the absence of reproduction.

The general framework of the DEB model for a larva is represented in Fig. 1 and main parameters of different equations of the model are given in Table 1. DEB theory is described below and the equations used were issued or adapted from the DEB model validated for adult $C$. gigas (Pouvreau et al., 2006). The notation and symbols used are from Kooijman (2000) and faithfully follow the rules: quantities that are expressed per unit of structural biovolume have square brackets, [ ]; quantities per unit of biosurface have braces, \{\} ; and rates, which have dots above them, indicate the dimension over time.

According to DEB theory, a larva can be described by three state variables: the energy in the reserve, $E$, the structural body volume, $V$, and the amount of energy invested into development to reach juvenile stage, $E_{R}$. The ingestion rate, $\&\left(\mu \mathrm{m}^{3} \mathrm{~d}^{-1}\right)$, is proportional to the biosurface of a larva, $V^{2 / 3}\left(\mu \mathrm{m}^{2}\right)$, and relies on available food density, $X$ (phytoplankton expressed in $\left.\mu \mathrm{m}^{3} \mu^{-1}\right)$, in the environment:

$$
\&=\{\& m\} \cdot f \cdot V^{2 / 3}
$$

where $\left\{\&_{m}\right\}$ is the maximum ingestion rate per unit of biosurface (expressed in $\mu \mathrm{m}^{3} \mathrm{~d}^{-1} \mu \mathrm{m}^{-2}$ ), $X_{K}$ is the half saturation coefficient $\left(\mu \mathrm{m}^{3} \mu \mathrm{l}^{-1}\right)$ and $f$ is the feeding functional response, which can vary between 0 and 1 (dimensionless).

The ingested food is converted into assimilates, which are added to the reserve, $E$, with constant assimilation efficiency (ae, dimensionless) according to a food energy conversion

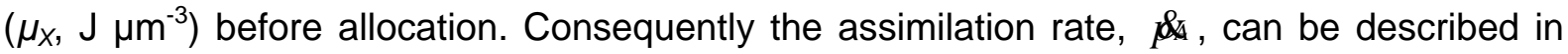
Eq. 2 as: 


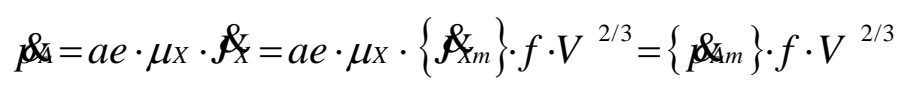

where $\left\{\mathrm{Am}_{m}\right\}$ is the maximum surface-area-specific assimilation rate expressed in $\mathrm{J} \mathrm{d}^{-1} \mathrm{~cm}^{-2}$. The assimilation efficiency was assumed to be 0.4 (Walne, 1965; Sprung, 1984) and the food

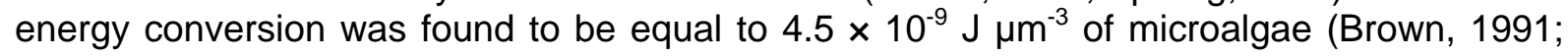
Brown and Robert, 2002).

The dynamics of the energy in the reserve, $E$, follow the energy conservation law and can be described as:

$$
\frac{d E}{d t}=\& A-p
$$

Energy is mobilised from this reserve pool to fuel the activities of organism at a rate called the catabolic power or utilisation rate, $\&$ :

$$
\&=\frac{E / V}{\left[E_{G}\right]+\kappa \cdot E / V}\left(\frac{\left[E_{G}\right] \cdot\left\{\alpha_{m}\right\} \cdot V^{2 / 3}}{\left[E_{m}\right]}+[\& M] \cdot V\right)
$$

An extended explanation of Eq. 4 can be found in Kooijman (2000). In summary, $E / V$ corresponds to the energy density in an organism $\left(\mathrm{J} \mathrm{cm}^{-3}\right)$, which may vary between 0 and the maximum energy density, $\left[E_{m}\right]\left(\mathrm{J} \mathrm{cm}^{-3}\right)$, according to the food density in the environment. The mobilized reserve is described by the allocation rule where the parameter $\kappa$ corresponds to a fixed fraction of utilisation rate, $\&$, spent on maintenance of somatic tissue, as absolute priority, and structural growth for larvae; the rest $(1-\kappa)$ goes to development and its maintenance during the larval stage. [ $\left.{ }_{1}\right]$ is a parameter that denotes the volume-specific maintenance rate $\left(\mathrm{J} \mathrm{d}^{-1} \mathrm{~cm}^{-3}\right)$. $\left[E_{G}\right]\left(\mathrm{J} \mathrm{cm}^{-3}\right)$ indicates the volume-specific costs for structural growth, $E_{V}$, with $\&$ as the flow of energy from the reserve allocated to this process. The fraction of catabolic power allocated to and can be defined as:

$$
\frac{d E_{V}}{d t}=\not \&=\kappa \cdot \& t-\not \&
$$

Maintenance costs, are scaled with volume and correspond to all processes that keep the organism alive. For example, for an oyster larva, this consists of the concentration gradients across membranes, osmoregulation, continuous shell production and mucociliary activity (Strathmann, 1979). Somatic maintenance has priority over growth; hence growth ceases when the flow $\kappa . \&$ of the mobilised reserve is equal to, or lower than, somatic 
maintenance demands. The energy of the reserve flow allocated to maintenance costs, can be expressed as:

$$
\$ 4=[\&] \cdot V
$$

where $\left[\mathrm{s}_{1}\right]$ is the volume-specific maintenance rate $\left(\mathrm{J} \mathrm{d}^{-1} \mu \mathrm{m}^{-3}\right)$ and $V$ the body volume $\left(\mu \mathrm{m}^{3}\right)$. Then, the dynamics for the structural body volume, $V$, are expressed in Eq. 6.

For larvae, DEB theory states that a fixed proportion $(1-\kappa)$ of the energy is spent on the one hand on development and on the other hand on the maintenance of this development. That means that larvae become more and more complex to reach adult stage. Growth and development are parallel processes in the DEB model. Accordingly the energy allocated to development plus its maintenance is equal to $(1-\kappa) \cdot$, which split into two fluxes, and \&s, respectively, and expressed in $\mathrm{J} \mathrm{d}^{-1}$. This remaining fraction can be defined as:

$$
\frac{d E_{R}}{d t}=\alpha R=(1-\kappa) \cdot R-\&
$$

with $E_{R}$ as energy allocated to development $\left(\mathrm{J} \mathrm{d}^{-1}\right)$.

This second flux for maintenance costs of development, fu $_{\text {, }}$ corresponds to the product of the energy allocated to development $(1-\kappa) / \kappa$, proportional to $V$ and [ $\$$ ]

$$
\&=V \cdot[\&] \cdot\left(\frac{1-\kappa}{\kappa}\right)
$$

DEB theory introduces a shape coefficient, which relates length measurement, $L$, to structural body volume, $V$, for an organism. This parameter is dimensionless and indicates that length has a specific relationship with volume in each species. During its development, an oyster larva does not have the same shape as an adult. Indeed, the shell only acquires its characteristic shape after metamorphosis. We therefore used a specific shape coefficient, $\delta_{M}$, to convert shell length into volume for larvae. As a first approximation, wet weights can be converted into physical volumes representing larval structure and reserves. Therefore, the shape coefficient can be expressed as the "minimal envelope" without reserves, and be estimated by using a calibration curve with the form:

$$
V=\left(\delta_{M} L\right)^{3}
$$

Physiological rates, such as ingestion and maintenance, depend on body temperature. This relation is usually well described by an Arrhenius-type equation within a species-specific 
tolerance range between upper and lower temperature boundaries (Kooijman, 2000). According to the Arrhenius relationship, this dependency can be expressed as:

$$
k \notin T)=k \& \cdot \exp \left\{\frac{T_{A}}{T_{1}}-\frac{T_{A}}{T}\right\}
$$

where $R(T)$ is the value of the physiological rate that depends upon an ambient temperature $T$ (in Kelvin), $k \&$ is the value of the physiological rate at a reference temperature $T_{1}$ of $298 \mathrm{~K}$ ( $25{ }^{\circ} \mathrm{C}$ in this study), and $T_{A}$ is the so-called Arrhenius temperature (in Kelvin). To take into account a tolerance range with temperature boundaries, the basic formula described above becomes:

$$
\mathscr{k}(T)=\mathbb{K}_{\mathbb{H}} \exp \left\{\frac{T_{A}}{T_{1}}-\frac{T_{A}}{T}\right\} \cdot\left(1+\exp \left\{\frac{T_{A L}}{T}-\frac{T_{A L}}{T_{L}}\right\}+\exp \left\{\frac{T_{A H}}{T_{H}}-\frac{T_{A H}}{T}\right\}\right)
$$

where $T_{L}$ and $T_{H}$ relate to the lower and upper boundaries and $T_{A L}$ and $T_{A H}$ are the Arrhenius temperatures for the rate of decrease at each boundary. All dimension temperatures are given in $\mathrm{K}$. For $C$. gigas larvae, $T_{L}$ and $T_{H}$ were estimated from the literature and these values were initially fixed at $13^{\circ} \mathrm{C}$ and $32^{\circ} \mathrm{C}$ (Abdel-Hamid et al., 1992; Helm and Millican, 1977 , respectively). As a first approximation, $T_{A L}$ and $T_{A H}$ values were both fixed at $75000 \mathrm{~K}$ (van der Veer et al., 2006).

\subsection{Specific additional assumptions for the larval stage}

There are a number of specific characteristics of larval feeding behaviour that first needed to be stated in the model. Larval life begins with a low feeding phase that lasts for 5 or 6 days, during which the reserves contained in the embryo itself are consumed (Ben Kheder et al., 2010). After this mixotrophic period, exotrophic feeding begins. Therefore, we established in the model that age at first strict exotrophic feeding, $a_{b}$, occurs at $5.5 \mathrm{~d}$ when larvae reach a size of about $100 \mu \mathrm{m}$. Thereafter during exotrophic phase a marked increase in ingestion rate is observed (Gerdes, 1983; Rico-Villa et al., 2008). This assumption about feeding periods was applied over a wide range of temperature $\left(17\right.$ to $\left.32{ }^{\circ} \mathrm{C}\right)$ based on experimental data (Rico-Villa et al., 2009). During the exotrophic period larvae aim to accumulate sufficient substrate reserves to allow them to meet the energy demands they will face during metamorphosis, and thus ensure their survival (Haws et al., 1993). Also, a temporary halt in ingestion is expected in pediveliger larvae to allow them to complete new structures for benthic life (Gerdes, 1983; Rico-Villa et al., 2008).

To take into account larval metamorphosis in the model, we assumed that some larvae achieved competence size earlier (>280 $\mu \mathrm{m}$ : Coon et al., 1990), underwent metamorphosis, and consequently disappeared from the population of larvae on which we were measuring mean size. As a result, we hypothesised that this precocity for some larvae is the reason for the plateau in larval growth that can be observed at the end of larval rearing experiments. To validate this hypothesis, we calculated the probability of metamorphosis of a larva as the cumulated normal distribution centred around $300 \mu \mathrm{m}$ (S.D. $20 \mu \mathrm{m}$ ) length at metamorphosis, $L_{m t}$; this also allowed the estimation of the new mean size of the population of larvae that had not yet metamorphosed. 


\subsection{Experimental protocol for parameter estimation}

Fertilisation and larval culture were carried out at the Argenton experimental hatchery (Ifremer, France) as detailed by Rico-Villa et al. (2006). Briefly, gametes were obtained by the gonad-stripping technique on adult oysters previously conditioned at $19{ }^{\circ} \mathrm{C}$. Embryo cultures were maintained at $25^{\circ} \mathrm{C}$ and salinity at $34 \mathrm{psu}$ in $150 \mathrm{I}$ rearing tanks of aerated $(0.5$ I $\mathrm{mn}^{-1}$ ) $1 \mu \mathrm{m}$ - filtered sea water for further development to the D-stage. All larval experiments were run starting with two-day-old D-stage larvae obtained by this method, and feeding supply was expressed in cell biovolume $\left(\mu \mathrm{m}^{3} \mu^{-1}\right)$.

Three independent experiments were run on oyster larvae:

In experiment $A$, body wet mass of larvae was assessed according to length to determine the shape coefficient, $\delta_{M}$.

In experiment $B$, the effects of temperature on larval growth were established to estimate the Arrhenius temperature, $T_{A}$.

In experiment $C$, larval ingestion was evaluated at different food density levels to calculate maximum surface area-specific ingestion rate, $\left\{\&_{m}\right\}$, and half saturation coefficient, $X_{K}$.

\subsubsection{Experiment A: Shape coefficient ( $\left.\delta_{M}\right)$ determination}

The shape coefficient parameter can be determined from the relationship between shell length and total body weight mass data for C. gigas larvae. Results from Gerdes (1983) and His and Maurer (1988) were combined with our own experimental data and expressed in dry tissue weight (DW). Our own dataset was acquired under the following conditions: larvae were reared in $150 \mathrm{I}$ tanks at 5 larvae $\mathrm{ml}^{-1}$, at $25^{\circ} \mathrm{C}$ and salinity $34 \mathrm{psu}$. Larvae were continuously fed Isochrysis affinis galbana (T-ISO: strain CCAP 927/14) and Chaetoceros calcitrans forma pumilum (strain CCAP 1010/05) at a 1:1 cell biovolume. Quantity of food supplied during larval and settlement stages depended on biomass increase, but a phytoplankton level of $1400 \mathrm{\mu m}^{3} \mu^{-1}$ was continuously maintained by progressively increasing the daily food ration at the entry to the rearing system, as detailed in Rico-Villa et al. (2008). Dry tissue weight and shell length were determined following methodologies described by His and Maurer (1988) and Rico-Villa et al. (2006), respectively, throughout the whole of larval development in these experiments. We calculated total body weight mass (ng) from DW data assuming that $80 \%$ of total body weight mass is due to water. Since the measured total body weight mass of larvae may include reserves as well as structure, the "minimal envelope" of the scatterplot, i.e. corresponding theoretically to body weight without reserves, was used to calculate the shape coefficient, $\delta_{M}$. To estimate parameters of this 'minimal envelope' based on the stochastic frontier analysis (Battese and Coelli, 1992), the frontier package from the $R$ software was used (http://cran.rproject.org/web/packages/frontier/index.html).

\subsubsection{Experiment $B$ : Arrhenius temperature $\left(T_{A}\right)$ determination}

The Arrhenius parameter, $T_{A}$, was determined from our own experiments and from relevant literature datasets (His et al., 1989) over a wide range of temperature. For our trials larvae were reared in a flow-through system to maintain a constant flow of algal cells and stable temperature conditions, and allow continuous hydrobiological data recording (Rico-Villa et al., 2008). Larvae were reared at a density of 30 larvae $\mathrm{ml}^{-1}$, at five different temperatures: $17,22,25,27$ and $32{ }^{\circ} \mathrm{C}$. Daily food ration consisted of a diet consisting of two species (1:1 in cell biovolume) of T-ISO and C. calcitrans forma pumilum (week 1 ) or $C$. gracilis (from 
week 2: strain UTEX LB2658). Food ration was adjusted as the larvae grew, allowing 1400 $\mu \mathrm{m}^{3} \mu^{-1}$ of phytoplankton to always be available. Each set of experimental conditions consisted of a test tank with larvae and food supply, and a control tank with only a constant flow of phytoplankton (no larvae), both at a defined temperature. D-stage larvae, initially reared at $25{ }^{\circ} \mathrm{C}$, were acclimated over one day at each temperature before the experiment began. Larval growth rate $\left(\mu \mathrm{m} \mathrm{d}^{-1}\right)$ was estimated using shell length data assessed during the exotrophic period where larvae fed exclusively on phytoplankton and exhibited a linear shell length increase. In the present work, data were standardized to a value of 1 for a reference temperature of $298 \mathrm{~K}\left(25^{\circ} \mathrm{C}\right)$. To estimate the Arrhenius parameter, growth rate data as function of temperature were used: a Newton-Raphsen algorithm written in Matlab ${ }_{\circledR}$ software was applied within the DEBtool package developed by Kooijman (http://www.bio.vu.nl/thb/deb/deblab/).

2.3.3. Experiment C: Maximum surface area-specific ingestion rate $\left\{\&_{m}\right\}$ and the half saturation coefficient $X_{K}$ determination

Values of these parameters were estimated using trials on maximum food uptake in relation to body volume/size at different phytoplankton density levels and at a constant temperature within the optimal temperature range for $C$. gigas larvae. Larvae were grown under rearing conditions similar to those described above, except that temperature was maintained at 25 ${ }^{\circ} \mathrm{C}$ and it was food supply that was varied. Larvae were thus continuously fed at several phytoplankton densities (expressed in cell biovolume) providing food availabilities of 70, 280, $450,960,1000,1900,2100$ and $3300{\mu m^{3}} \mathrm{l}^{-1}$. The lowest value, $70 \mu \mathrm{m}^{3} \mu^{-1}$, considered as minimal amount of particles, was that found in tank seawater after $1 \mu \mathrm{m}$ filtration when no phytoplankton was added. Such value has been currently recorded in our surroundings all the year round, after fine filtration, because of sea water oligotrophic condition. This "negative control" corresponded to the amount of picoplankton measured on electronic counter including accordingly apparatus line base noise. Food densities from 200 to $500 \mu^{3}$ $\mu \mathrm{l}^{-1}$ were considered as low diets; $700-1000 \mu \mathrm{m}^{3} \mu \mathrm{l}^{-1}$ as restricted diets, and 2000 to 3250 $\mu \mathrm{m}^{3} \mu^{-1}$ as ad libitum feeding. Shell length was measured during the larval experiments using an image analysis technique. To obtain the ingestion rate for larvae, each tank water outflow was analysed for fluorescence measurements. Six to seven fluorescence recordings per day and per tank were standardized to phytoplankton density, expressed in biovolume $\left(\mu \mathrm{m}^{3} \mu^{-1}\right)$, by means of an electronic particle counter (Multisizer III) equipped with a 100- $\mu \mathrm{m}$ aperture tube. The ingestion rate (IR) was estimated as follows:

$$
\mathbf{I R}=\left[\left(\mathbf{C}_{\mathbf{C}}-\mathbf{C}_{\mathbf{L}}\right) * \mathbf{F R}\right] / V^{2 / 3}
$$

where IR is expressed in $\mu m^{3}$ per day and per unit structural surface $\left(\mu m^{3} d^{-1} \mu m^{-2}\right), C_{C}$ is the phytoplankton density $\left(\mu \mathrm{m}^{3} \mathrm{I}^{-1}\right)$ in the control tank, $\mathrm{C}_{\mathrm{L}}$ is the phytoplankton density $\left(\mu \mathrm{m}^{3} \mathrm{I}^{-1}\right)$ in the larval rearing tank, FR is the flow rate through each tank $\left(\mathrm{I} \mathrm{d}^{-1}\right)$ and $V^{2 / 3}$ is the structural surface of the larva $\left(\mu \mathrm{m}^{2}\right)$. IR by larvae at different algal cell densities was standardized to plot the relationship between food levels and IR on Matlab® software in order to evaluate the feeding function response of $C$. gigas larvae and calculate feeding parameters from Eq. 1. The feeding functional response, $f$, can be modelled according two types of equation : the type 3 sigmoid ("S-shaped") function: $f=\frac{X^{2}}{X^{2}+X_{K}^{2}}$ or the type 2 hyperbolic 
function, $f=\frac{X}{X+X_{K}}$. The type 3 response differs from type 2 because the sigmoid model exhibits a point of inflection at low $X$-values, i.e. when food is scarce (Holling, 1959; Gentleman et al., 2003). It has been previously used for other oyster larvae such as those of Crassostrea virginica (Baldwin and Newell, 1995). In contrast, type 2 was applied in adult oyster (Pouvreau et al, 2006). To perform this non linear regression, a Newton-Raphsen algorithm written in Matlab ${ }^{\circledR}$ software was applied within the DEBtool package developed by Kooijman (http://www.bio.vu.nl/thb/deb/deblab/).

\subsection{Model simulation and validation}

Three state variables of the larval DEB model were run on Matlab® software using the DEBtool package; these represented energy in reserves $(E)$, energy in structure $\left(E_{V}\right)$ and energy in development $\left(E_{R}\right)$ according to their respective equations (Eqs. 3, 5 and 7). Other parameter values used in this study were taken from Pouvreau et al. (2006).

The energy content of an egg, $E_{0}$, was around $6 \times 10^{-4} \mathrm{~J}$ based on experimental measurements of proteins, lipids and carbohydrates, which are considered to be the main energy substrates. However, since the model was run from day 2 (D-stage), the energy content in the structural volume of a larva, $V_{2}$, was calculated at around $2.5 \times 10^{-4} \mathrm{~J}$. An initial approximation of the energy content in reserves, $E_{2}$, was also assumed to be around $2.5 \times$ $10^{-4} \mathrm{~J}$. The remainder of the total egg energy content, $E_{0}$, corresponded to dissipation due to energy conversion. To verify this assumption, we made test runs of the model with these different values of initial energy content and they did not have any notable effect on the simulations.

The forcing variables used to run the model were the seawater temperature (within the tolerance range) and the food density expressed in phytoplankton cell biovolume $\left(\mu \mathrm{m}^{3} \mu^{-1}\right)$, which corresponded to the controlled parameters in the experiments we made for this study. The state variable $E_{V}$ was transformed into length, $L$, according to:

$$
L=\left(E_{V} /\left[E_{G}\right]\right)^{1 / 3} / \delta_{M}
$$

Finally, growth data from other larval cultures ("external data") were used to validate our DEB model. In these cultures, larvae were reared at $25^{\circ} \mathrm{C}$, salinity 34 psu and continuously fed a diet of Isochrysis affinis galbana strain T-ISO and C. calcitrans forma pumilum (1:1 in cell biovolume) with a constant phytoplankton availability of $1400{\mu \mathrm{m}^{3}}^{3} \mathrm{ll}^{-1}$. Shell length was measured during larval cultures using image analysis.

For all simulations, the goodness of fit between observations $(X)$ and predictions of the model $(Y)$ was evaluated and compared using linear regression statistics $\left(\mathrm{R}^{2}\right.$, slope and residual standard deviation) using Matlab ${ }^{\circledR}$ software.

\section{Results}

\subsection{Parameter estimates}


The calculated value of the shape coefficient, $\delta_{M}$ ( \pm S.E.), for $C$. gigas larvae was $0.658 \pm 0.008$ (Fig. 2, $t$-value $=-33.87$ and $p<0.0001$ ). Throughout larval development, the somatic wet weight increased from D-stage $(120 \mathrm{ng})$ to eyed pediveliger stage $(5500-7500$ ng).

The lower, $T_{L}$, and upper, $T_{H}$, boundaries of the temperature tolerance range were fixed at 285 and $306 \mathrm{~K}$, respectively (Fig. 3). The Arrhenius temperature, $T_{A},( \pm$ S.E.), which corresponds to the slope of the increase with this adjustment, was estimated at $11000 \pm$ $2500 \mathrm{~K}$ for $C$. gigas larvae. The Arrhenius temperature of the rate of decrease at the lower temperature boundary, $T_{A L}$, and at the upper boundary, $T_{A H}$, were both fixed at $75000 \mathrm{~K}$.

The feeding functional response, $f$, for $C$. gigas larvae at different phytoplankton density levels is shown on figure 4 and appears to be "S-shaped". The type 3 sigmoid function gave the best adjustment $\left(R^{2}=0.938\right)$ and the estimation of the two ingestion parameters for larvae reared at $25{ }^{\circ} \mathrm{C}$ was: $137 \pm 3 \mu \mathrm{m}^{3} \mathrm{~d}^{-1} \mu \mathrm{m}^{-2}$ for the maximum surface area-specific

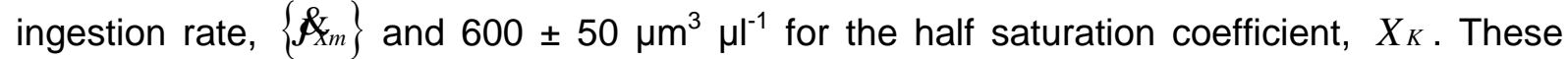
parameter values are listed in Table 1 , together with all the other DEB parameter values for C. gigas larvae.

\subsection{Model simulation and validation}

All simulations were initialised by introducing larval length data from day 2 . They ended when the larvae reached the size of $300 \mu \mathrm{m}$ at which process of metamorphosis occurred.

\subsubsection{Simulation of temperature effects}

Simulations of the effects of five different temperatures on larval growth are shown in Fig. 5 . The other environmental conditions were assumed to be optimal with a mean salinity of 34 psu and a food density of $1400{\mu \mathrm{m}^{3}}^{3} \mathrm{ll}^{-1}$. The model had a well matched fit with data collected on larval growth, with high coefficients of determination $\left(R^{2} \geq 0.97\right)$ between simulation and observed data for all temperatures (Table 2). Similarly, the slope of the regression was close to 1 at all temperatures, although the lowest value was recorded at $17{ }^{\circ} \mathrm{C}(0.831)$. At $17^{\circ} \mathrm{C}$ there was also a higher residual standard deviation (19.80) than for the other temperatures where it was narrower (11.5 to 17.3, Table 2). Values for mean deviation tended to be slightly over-estimated in the simulations, particularly at $17^{\circ} \mathrm{C}$ where a value of $\approx 16.2$ was obtained (Table 2). The form of larval growth curves showed a clear pattern in relation to temperature, with slopes becoming sharper at higher temperatures (Fig. 5). This effect showed that the strong influence that temperature has on growth is intrinsically related to feeding activity during larval life. One of the main characteristics of larval development, taken into account in the specific assumptions made in this model is the mixotrophic period from D-stage to early umbone larva of $\approx 110 \mu \mathrm{m}$ length, which lasted $5 \mathrm{~d}$ when larvae were reared between 22 and $32{ }^{\circ} \mathrm{C}$ (Figs. $5 \mathrm{~b}$ to $5 \mathrm{e}$ ). At $17^{\circ} \mathrm{C}$, in contrast, the mixotrophic period took $10 \mathrm{~d}$ before larvae reached $\approx 110 \mu \mathrm{m}$ length (Fig. $5 \mathrm{a}$ ). The exotrophic period lasted different lengths of time depending on temperature. This feeding period, from umbone larvae to eyed pediveliger of $\approx 300 \mu \mathrm{m}$ length, lasted $10 \mathrm{~d}$ at 27 and $32{ }^{\circ} \mathrm{C}$ (Figs. 5d and 5e). At 22 and $25{ }^{\circ} \mathrm{C}$ the exotrophic periods lasted 13 to $16 \mathrm{~d}$ (Figs. $5 \mathrm{~b}$ and $5 \mathrm{c}$ ) while it lasted at least 25 days at $17^{\circ} \mathrm{C}$ (Fig. 5a). Increased temperature enhanced larval growth, resulting in a shorter larval rearing period. When the larvae reached $\approx 300 \mu \mathrm{m}$ shell length, we assumed that they were competent to undergo metamorphosis. Therefore, simulations showed that timing of metamorphosis decreased with increasing temperature. Metamorphosis was achieved in less than $15 \mathrm{~d}$ at 27 and $32{ }^{\circ} \mathrm{C}$ while at 22 and $25^{\circ} \mathrm{C}$ such process occurred above $20 \mathrm{~d}$. Lastly, larvae reared at $17{ }^{\circ} \mathrm{C}$ never reached theoretical competence size $(300 \mu \mathrm{m})$. Nevertheless, $16 \%$ of settlement was recorded at $17{ }^{\circ} \mathrm{C}$ on day 35 and length measurements suggested 
metamorphosis at $285 \mu \mathrm{m}$ (Rico-Villa et al., 2009). Such simulations showed that the DEB model adequately describes oyster growth during larval development under different thermal conditions.

\subsubsection{Simulation of food density effects}

When other environmental conditions were considered to be optimal (34 psu and $25{ }^{\circ} \mathrm{C}$ ) increasing food density enhanced larval growth (Fig. 6). At the lowest phytoplankton density $\left(70 \mu \mathrm{m}^{3} \mu^{-1}\right)$ corresponding to $1 \mu \mathrm{m}$ filtered seawater with no additional microalgae the model response and laboratory data fitted accurately (Fig. 6a). However such simulation has a bias. Indeed no larval growth occurred and larvae did not undergo metamorphosis. Though a good coefficient of correlation $\left(R^{2}=0.95\right)$ was found the slope of regression was over estimated (9.865: Table 3). In this particular case, error is higher than growth increment and accordingly such fitting is meaningless. Simulation at very low food density $\left(280 \mu^{3} \mu^{-1}\right)$ did not accurately fit observed larval growth (Fig. 6b). One explanation may be that high mortalities occurred at this food level from day 10 and metamorphosis was never reached. Thus we assumed that these larvae were highly food limited and destined to die. Simulation

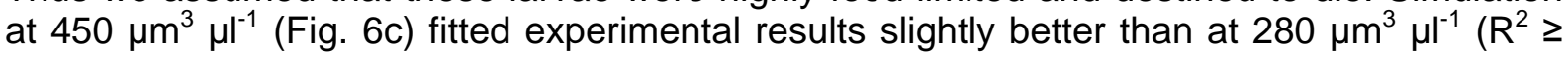
0.98 vs. 0.61 respectively; Table 3). Nevertheless at both food densities, values for mean

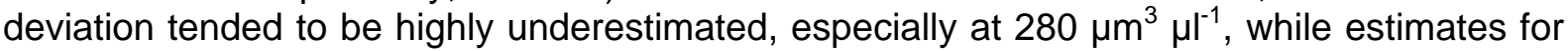
residual standard deviation remained high (Table 3 ).

The larval growth curves obtained from the simulations using food densities from 960 to 3300 $\mu \mathrm{m}^{3} \mu^{-1}$ agreed accurately with the growth observed in laboratory experiments (Figs. 6d to $6 h)$. The regression parameters confirmed this fit with high coefficients of determination $\left(R^{2} \geq\right.$ 0.96 ) between the simulation and experimental data (Table 3). The slope of the regression was very close to 1 in these simulations, and values for residual standard deviation between prediction and observation were low. In contrast, mean deviation values tended to be moderately underestimated in simulations at 960 and $1000 \mu \mathrm{m}^{3} \mu^{-1}$, and predictions led to slight overestimations of growth at 1900,2100 and $3300{\mu m^{3}}^{3} l^{-1}$ (Table 3). Overall in

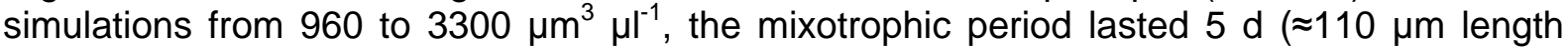
size). Thereafter the exotrophic period, from early umbone larva to metamorphosis, did not show differences in length within simulations over this range of food density conditions. Therefore, to provide an optimal food supply that will enhance larval growth and success at metamorphosis, phytoplankton availability should be held at a minimum level of $1000 \mu \mathrm{m}^{3} \mu \mathrm{l}^{-}$.

\subsubsection{External validation of DEB model}

Finally, the DEB model was validated on growth data from four other larval cultures. These data were recorded under optimal environmental conditions: $34 \mathrm{psu}, 25^{\circ} \mathrm{C}$ and $1400 \mu \mathrm{m}^{3} \mu^{-}$ ${ }^{1}$. Comparison of the DEB model with the observed larval growth showed a correct fit with all these "external" rearing cultures (Fig. 7). The simulations provided high coefficients of determination $\left(R^{2} \geq 0.99\right)$ between prediction and observed data (Table 4). The other regression parameters showed a strong relationship, with the slope of the regression close to 1 and low values for residual standard deviation between simulation and observation. Values for mean deviation tended to be slightly over-predicted in the simulations (Table 4). In all cases, the mixotrophic period lasted $5 \mathrm{~d}$, corresponding to a larval length size around 110 $\mu \mathrm{m}$. Thereafter, the exotrophic period from early umbone to pediveliger larva did not show differences in length or success at metamorphosis among these four simulations. 


\section{Discussion}

For several decades, bioenergetic modelling approaches have mainly focused on the adult stage of Pacific oyster C. gigas (Barillé et al., 1997; Ren and Ross, 2001; Gangnery et al., 2003; Pouvreau et al., 2006). With respect to the oyster larval stage, Dekshenieks et al. (1993) built a first model for C. virginica larvae, which illustrated the effects of environmental variables on growth and development. However, laboratory measurements were not available to cover growth rates during the whole of larval development and so the authors applied a recurrent interpolation for larvae above $250 \mu \mathrm{m}$. In addition, C. virginica experimental measurements were insufficient to establish relationships over a wide range of environmental conditions, e.g. temperature effects on ingestion rate. For C. gigas larvae, a model has been proposed to simulate growth and survival (Bochenek et al., 2001), which has since been used in other studies (Powell et al., 2002; Hofmann et al., 2004). This model, based on biochemical principles, succeeds in simulating some of the basic characteristics of C. gigas larvae. Nevertheless, the model has the major limitation of only being valid over a narrow range of environmental conditions, since most simulations were run at the optimal temperature of $25{ }^{\circ} \mathrm{C}$. Further experimental data is therefore needed for validation of this model. In contrast, our present model has been validated throughout the entire development of C. gigas larvae and over a wide range of environmental conditions. Moreover, the biochemical model of Bochenek et al. (2001) is based on the scope for growth (SFG) concept (Bayne, 1976). The idea behind the SFG concept is that the energy equivalent of respiration is directly subtracted from the energy derived from assimilated food, the remainder being available for growth. The fundamental difference in DEB theory, as Kooijman (2000) explains, is that respiration rates encompass metabolic costs as well as growth costs. Therefore, respiration is a composite of many physiological processes and, in this context, cannot be subtracted from food as in the SFG concept. Moreover, respiration rates are measured over short periods during which the actual growth of the body is negligible. Since the DEB model does not use respiration rates as a primary variable, interpretation problems of this kind are nonexistent. As this variable is optional in the DEB theory, respiration is sometimes used just to test the model.

The choice of a DEB model in the present study was primarily motivated by the simplicity of several aspects of this type of model, including a relatively short list of assumptions, which can be considered "mechanistic". A powerful quality of DEB theory is that the model is not species-specific, i.e. intra and interspecies differences can be handled within the same model framework (Kooijman, 2000). The only difference between such different applications of the model is in the parameter values. The present study applies this principle. Some of the parameters were obtained from specific experiments on larvae, while others were taken from the existing adult oyster model developed by Pouvreau et al. (2006). The resulting version of the DEB model for oyster larvae was then applied and validated to demonstrate its capacity to reliably reproduce oyster larval growth compared with results from several ecophysiological experiments. The results provide insights into how seawater temperature and food density, as governing environmental factors, affect growth throughout larval development from the $\mathrm{D}$-stage to pediveliger larvae. One major problem when using DEB theory is in the estimation of the DEB parameters. In our study, the proven agreement between the simulation results and experimental observations shows that most of the estimates we used can be considered as fairly reliable under the laboratory conditions employed.

With regard to DEB parameters governing food consumption, our results showed that the relationship between food density and ingestion rates for $C$. gigas larvae appeared to be consistent with a sigmoidal function (type 3) (Holling, 1959). This function assumes that ingestion rate exhibits a curved response to increasing food levels, subsequently followed by a plateau (Gentleman et al., 2003). These observations in ingestion rate may indicate developmental plasticity for adaptation of larvae to low or high food densities (Strathmann et 
al., 1993). Nevertheless, the present type 3 feeding response does not follow the assumptions proposed in DEB theory, where ingestion rate generally follows a type 2 functional response to food density. More precise laboratory experiments are therefore required to improve our understanding of the feeding response of $C$. gigas larvae and to confirm or refute our choice of a type 3 curve, especially for high food concentration which are rarely encountered in natural surroundings. However, this type 3 functional response was chosen because it has been successfully applied to feeding response of $C$. virginica larvae (Baldwin and Newell, 1995). These authors demonstrated that a sigmoid feeding response seemed to be adequate to quantitatively reproduce ingestion rate, using phyplankton biovolume $\left(\mu \mathrm{m}^{3} \mu^{-1}\right)$ as a food quantifier. This last feature of feeding behaviour was in agreement with our study on $C$. gigas larvae.

With regard to DEB parameters related to temperature effects, results showed that $C$. gigas larvae exhibit a high value of Arrhenius temperature, $T_{A},(11000 \mathrm{~K})$ over a wide thermal range. Arrhenius temperature is typically high for species that naturally experience small temperature changes, such as those that occur in pelagic species or in pelagic life stages (e.g. planktotrophic larvae, like oysters). The present study confirms that larval growth increases markedly with increasing temperature, as previously reported (Helm and Millican, 1977; His et al., 1989; Abdel-Hamid et al., 1992). Another trend observed in the temperature simulations was the shortening of larval life. This trend is already documented for oyster larvae (Davis and Calabrese, 1964), mainly at the warmer temperatures (below lethal temperature). C. gigas larvae therefore proved to be eurythermic but had major thermodependency between 22 and $32{ }^{\circ} \mathrm{C}$. Future laboratory experiments should include temperatures, above and below the boundaries tested here, to confirm our $T_{A}$ and threshold values and its validation in the model.

As mentioned above, one of the most attractive aspects of the DEB theory is the ability to compare different species by examining the differences or similarities in DEB parameter values (van der Veer et al., 2006). A previous study concerning the DEB theory applied to the larval stage in Macoma balthica (Bos et al., 2006) can be compared with our own. For example, the $T_{A}$ estimate for $M$. balthica is $7596 \mathrm{~K}$ over a range of temperature from cold to temperate values $\left(7\right.$ to $17{ }^{\circ} \mathrm{C}$ ), though it was $11000 \mathrm{~K}$ for $\mathrm{C}$. gigas over a wider range of temperature $\left(17\right.$ to $\left.32{ }^{\circ} \mathrm{C}\right)$. This broad range of temperature tolerance might explain the wide distribution of C. gigas among temperate and subtropical areas (Goulletquer et al., 1999; Langdon et al., 2003; Sicard et al., 2006) and its progressive geographical extension into new environments (Diederich et al., 2005; Brandt et al., 2008), since its larvae are able to tolerate temperate $\left(17{ }^{\circ} \mathrm{C}\right)$ to warm $\left(32{ }^{\circ} \mathrm{C}\right)$ seawater temperatures. Another example concerns comparison of DEB parameter values related to food consumption (i.e. $\left\{\&_{m}\right\}, X_{K}$ and $\left\{\alpha_{m}\right\}$ ) between the larvae of these two species. Estimates of $\left\{\&_{m}\right\}$ are in the same range of value for $M$. balthica $\left(95 \mu \mathrm{m}^{3} \mathrm{~d}^{-1} \mu \mathrm{m}^{-2}\right)$ and $C$. gigas $\left(35 \mu \mathrm{m}^{3} \mathrm{~d}^{-1} \mu \mathrm{m}^{-2}\right)$ at $15^{\circ} \mathrm{C}$. A similar trend may also be found for the values of $X_{K}$, which were 310 and $600 \mu \mathrm{m}^{3} \mu^{-1}$ for $M$. balthica and $C$. gigas, respectively. This similarity may be related to feeding patterns controlled by the cilia that enable both bivalve species to reach maximal ingestion by catching food with the velum. In contrast a major difference was observed in estimates of $\left\{\&\right.$, w w $104 \mathrm{~J} \mathrm{~d}^{-1} \mathrm{~cm}^{-2}$ for $M$. balthica and $6.5 \mathrm{~J} \mathrm{~d}^{-1} \mathrm{~cm}^{-2}$ for $C$. gigas at $15{ }^{\circ} \mathrm{C}$. This difference suggests that larvae of these species may differ in energy assimilation and utilization (Sprung, 1984). However, according to van der Veer et al. (2006), it remains unclear how certain interspecies variation in parameter values occurs, though these may be related to variability in environmental conditions, genetic variability or phenotypic plasticity. However, in the present comparison, differences between estimated parameters were probably linked to the energy budget calculations for $M$. balthica larvae, which were only realized on individuals of $200 \mu \mathrm{m}$ length, while in the field larvae may range from 50 to 400 $\mu \mathrm{m}$ (Bos et al., 2006). Therefore, the estimation procedure itself and the reduced number of data used to determine the parameters are sources of uncertainty in the energy budget of $M$. balthica larvae. 
One other important quality of DEB theory is that the generic aspect makes it possible to compare the bioenergetics of different life stages within a single species. One example concerns the temperature dependence in the optimal range, $T_{A}$, which appears to be different between larvae and adults of $C$. gigas (11 000 and $5800 \mathrm{~K}$, respectively). As mentioned, $T_{A}$ has a high value when the species experiences only small temperature changes, like these that normally occur during larval life. Larvae are present only after spawning events in summer when seawater temperature is maximal. In contrast, an adult oyster experiences a wider range of temperature $\left(3\right.$ to $\left.32{ }^{\circ} \mathrm{C}\right)$ as it lives throughout the year in seashore areas; adult oysters therefore exhibit a lower $T_{A}$ value than larvae.

Finally, all simulations were run including the success for a larva to metamorphose defined as the moment when it attains a shell length of $\geq 300 \mu \mathrm{m}$, as a first approximation of the trigger for metamorphosis. However, knowledge on this issue is limited and a full explanation of how factors control metamorphosis is lacking (Coon et al., 1990; Berias and Widdows, 1995). Further investigations are therefore needed to find another suitable trigger/indicator for metamorphosis, apart from shell length, to verify this first assumption and model metamorphosis.

In conclusion, the DEB model for Crassostrea gigas larvae has demonstrated its accuracy for simulating growth, development and metamorphosis under controlled conditions of seawater temperature and food density. Therefore, the model can be used to improve culture conditions in hatchery or knowledge of ecological requirements in surroundings. The estimation of DEB parameters was made using specifically designed experiments for these two key environmental factors. The extension of the DEB model from oyster adult to larva presented in this paper supports the attractive aspect of a generic model applied to the Pacific oyster $C$. gigas. The next step will be to investigate the feasibility of a unique DEB model to simulate growth from larvae to adult. Thus to encompass the whole life cycle of $C$. gigas, further studies must focus on post larval and juvenile stages. However, this bioenergetic model approach is not species-specific and can thus be applied to other bivalve larvae after previous determination of specific DEB parameters (e.g. ingestion and temperature). The model could also form a valuable part of a field ecosystem model to assess the influence of environmental factors on Pacific oyster culture and reproduction.

\section{Acknowledgements}

Benjamin Rico-Villa and Ismaël Bernard would like to acknowledge CONACyT (Mexico) and Ifremer and Conseil Régional de Poitou Charentes (France) for their respective support of this study through scholarships. The authors also wish to thank Dr Gaétan Daigle (Laval University at Québec) for his statistical assistance in 'stochastic frontier' analysis method.

\section{References}

Abdel-Hamid, M.E., Mona, M.H., Khalil, A.M. 1992. Effects of temperature, food and food concentrations on the growth of the larvae and spat of the edible oyster Crassostrea gigas (Thunberg). J. Mar. Biol. Assoc. India 34(1\&2), 195-202.

Bacher, C., Gangnery, A. 2006. Use of dynamic energy budget and individual based models to simulate the dynamics of cultivated oyster populations. J. Sea Res. 56, 140-155.

Baldwin, B.S., Newell, R.I.E., 1995. Feeding rate responses of oyster larvae (Crassostrea virginica) to seston quantity and composition. J. Exp. Mar. Biol. Ecol. 189, 77-91. 
Barillé, L., Héral, M., Barillé-Boyer, A.L., 1997. Modélisation de l'écophysiologie de l'huître creuse Crassostrea gigas dans un environnement estuarien. Aquat. Living Resour. 10, 3148.

Battese, G. E., Coelli, T. J., 1992. Frontier production functions, technical efficiency and panel data: With application to paddy farmers in India. Journal of Productivity Analysis 3, 153-169

Bayne, B.L., 1976. Marine Mussels: Their Ecology and Physiology. Cambridge University Press, Cambridge. 506 pp.

Ben Kheder, R., Quéré, C., Moal, J.,. Robert R., 2010. Effect of nutrition on Crassostrea gigas larval development and the evolution of physiological indices. Part A: quantitative and qualitative diet effects. Aquaculture accepted.

Berias, R., Widdows, J., 1995. Induction of metamorphosis in larvae of the oyster Crassostrea gigas using neuroactive compounds. Mar. Biol. 123, 327-334.

Bochenek, E.A., Klinck, J.M., Powell, E.N., Hofmann, E.E. 2001. A biochemically based model of the growth and development of Crassostrea gigas larvae. J. Shellfish Res. 20(1), 243-265.

Bos, O. G., Hendriks, I. E., Strasser, M., Dolmer, P., Kamermans, P. 2006. Estimation of food limitation of bivalve larvae in coastal waters of north-western Europe. J. Sea Res. 55(3): 191-206.

Bourles, Y., Alunno-Bruscia, M., Pouvreau, S., Tollu, G., Leguay, D., Arnaud, C., Goulletquer, P., Kooijman, S.A.L.M., 2009. Modelling growth and reproduction of the Pacific oyster Crassostrea gigas: Advances in the oyster-DEB model through application to a coastal pond. J. Sea Res. 62, 62-71.

Brandt, G., Wehrmann, A., Wirtz, K.W., 2008. Rapid invasion of Crassostrea gigas into the German Wadden Sea dominated by larval supply. J. Sea Res. 59, 279-296.

Brown, M.R. 1991. The amino acid and sugar composition of 16 species microalgae used in mariculture. J. Exp. Mar. Biol. Ecol. 145, 79-99.

Brown, M., Robert, R. 2002. Preparation and assessment of microalgal concentrates as feeds for larval and juvenile Pacific oyster (Crassostrea gigas). Aquaculture 207, 289-309.

Coon, S.L., Fitt, W.K., Bonar, D.B., 1990. Competence and delay of metamorphosis in the Pacific oyster Crassostrea gigas. Mar. Biol. 106, 379-387.

Davis, H.C., Calabrese, A., 1964. Combined effects of temperature and salinity on development of eggs and growth of larvae of Mercenaria mercenaria and Crassostrea virginica. Fish. B. 63, 643-655.

Dekshenieks, M.M., Hofmann, E.E., Powell, E.N. 1993. Environmental effects on the growth and development of Eastern oyster, Crassostrea virginica (Gmelin, 1791), larvae: a modelling study. J. Shellfish Res. 12, 241-254.

Diederich, S., Nehls, G., van Beusekom, J.E.E., Reise, K., 2005. Introduced Pacific oysters (Crassostrea gigas) in the northern Wadden Sea: invasion accelerated by warm summers? Helgoland Mar. Res. 59, 97-106. 
Dove, M.C., O'Connor, W.A., 2007. Salinity and temperature tolerance of Sydney rock oysters Saccostrea glomerata during early ontogeny. J. Shellfish Res. 26, 939-947.

FAO. 2008. Fisheries and Aquaculture Department. Aquaculture production 1950-2006. Fishstat Plus 2.3. Food and Agricultural Organisation, United Nations, Rome.

Gangnery, A., Chariband, J., Lagarde, F., Le Gall, P., Oheix, J., Bacher, C., Buestel, D., 2003. Growth model of the Pacific oyster Crassostrea gigas, cultured in Thau Lagoon (Méditerranée, France). Aquaculture 215, 267-290.

Gentleman, W., Leising, A., Frost, B., Strom, S., Murray, J., 2003. Functional responses for zooplankton feeding on multiple resources: a review of assumptions and biological dynamics. Deep Sea Res. Pt II 50, 2847-2875.

Gerdes, D. 1983. The Pacific oyster Crassostrea gigas. Part I. Feeding behavior of larvae and adults. Aquaculture 31, 195-219.

Goulletquer, P., Wolowicz, M., Latala, A., Gearion, P., Huvet, A., Boudry, P., 1999. Comparative analysis of oxygen consumption rates between, cupped oyster spat of Crassostrea gigas of French, Japanese, Spanish and Taiwanese origins. Aquat. Living Resour. 12(4), 271-277.

Haws, M.C., DiMichele L., Hand S.C., 1993. Biochemical changes and mortality during metamorphosis of the Eastern oyster Crassostrea virginica and the Pacific oyster Crassostrea gigas. Mol. Mar. Biol. Biotechnol. 2, 207-217.

Helm, M.M., Millican P.F., 1977. Experiments in the hatchery of Pacific oyster (Crassostrea gigas Thunberg). Aquaculture 11, 1-12.

Helm, M.M., Bourne, N., Lovatelli, A. 2004. Hatchery culture of bivalves. A practical manual. FAO Fisheries Technical Paper. No. 471. Rome, FAO. 177p.

His, E., Maurer, D. 1988. Shell growth and gross biochemical composition of oyster larvae (Crassostrea gigas) in the field. Aquaculture 69, 185-194.

His, E., Robert, R., Dinet, A. 1989. Combined effects of temperature and salinity on fed and starved larvae of the Mediterranean mussel, Mytilus galloprovincialis and the Japanese oyster Crassostrea gigas. Mar. Biol. 100, 455-463.

Hofmann, E. E., Powell, E.N., Bochenek, E.A., Klinck, J.M., 2004. A modelling study of the influence of environment and food supply on survival of Crassostrea gigas larvae. J. Mar. Sci. Technol. 61, 596-616.

Holling, C.S., 1959. Some characteristics of simple types of predation and parasitism. Can. Entomol. 91, 824-839.

Kooijman, S. A. L. M., 2000. Dynamic Energy and Mass Budgets in Biological Systems. Cambridge University Press. 424 pp.

Langdon, C., Evans, F. Jacobson, D., Blouin, M., 2003. Improved family yields of Pacific oyster Crassostrea gigas (Thunberg) derived from selected parents. Aquaculture 220, 227244. 
Lemos, M.B.N., Nascimento, I.A., De Araujo, M.M.S., Pereira, S.A., Bahia, I., Smith, D.H. 1994. The combined effects of salinity, temperature, antibiotics and aeration on larval growth and survival of the mangrove oyster, Crassostrea rhizophorae. J. Shellfish Res. 13, 187-192.

Pouvreau, S., Bourles, Y., Lefebvre, S., Gangnery, A., Alunno-Bruscia, M., 2006. Application of a dynamic energy budget model to the Pacific oyster, Crassostrea gigas, reared under various environmental conditions. J. Sea Res. 56, 156-167.

Powell, E.N., Bochenek, E.A., Klinck, J.M., Hofmann, E.E., 2002. Influence of food quality and quantity on the growth and development of Crassostrea gigas larvae: a modeling approach. Aquaculture 210, 89-117.

Ren, J.S., Ross, A.H., 2001. A dynamic energy budget model of the Pacific oyster Crassostrea gigas. Ecol. Model. 142, 105-120.

Ren, J.,S., Schiel, D., R., 2008. A dynamic energy budget model: parameterisation and application to the Pacific oyster Crassostrea gigas in New Zealand waters. J. Exp. Mar. Biol. Ecol. 361, 42-48.

Rico-Villa, B., Le Coz, J.R., Mingant, C., Robert, R. 2006. Influence of phytoplankton diet mixtures on microalgae consumption, larval development and settlement of the Pacific oyster Crassostrea gigas (Thunberg). Aquaculture 256, 377-388.

Rico-Villa, B., Woerther, P., Mingant, C., Lepiver, D., Pouvreau, S., Hamon, M., Robert, R., 2008. A flow-through rearing system for ecophysiological studies of Pacific oyster Crassostrea gigas larvae. Aquaculture 282, 54-60.

Rico-Villa, B., Pouvreau, S., Robert, R., 2009. Influence of food density and temperature on ingestion, growth and settlement of Pacific oyster larvae, Crassostrea gigas, Aquaculture 287, 395-401.

Robert, R., His, E., Dinet, A. 1988. Combined effects of temperature and salinity on fed and starved larvae of the European flat oyster Ostrea edulis. Mar. Biol. 97, 95-100.

Sicard, M.T., Maeda-Martínez, A.N., Lluch-Cota, S.E., Lodeiros-Seijo, C., Roldán-Carrillo, L.M., Mendoza-Alfaro, R., 2006. Frequent monitoring of temperature: an essential requirement for site selection in bivalve aquaculture in tropical-temperate transition zones. Aquacult. Res. 37, 1040-1049.

Sprung, M., 1984. Physiological energetic of mussel larvae (Mytilus edulis). IV. Efficiencies. Mar. Ecol. Prog. Ser. 18, 179-186.

Strathmann, R.R. 1979. Egg size, larval development and juvenile size in benthic marine invertebrates. Am. Nat. 111, 373-376.

Strathmann, R.R., Fenaux, L., Sewell, A.T., Strathmann, M.F., 1993. Abundance of food affects relative size of larval and postlarval structures of a molluscan veliger. Biol. Bull. 185, 232-239.

van der Veer, H.W., Cardoso, J.F.M.F., van der Meer, J., 2006. The estimation of DEB parameters for various Northeast Atlantic bivalve species. J. Sea Res. 56, 107-124.

Walne, P. R., 1965. Observations on the influence of food supply and temperature on the feeding and growth of the larvae of Ostrea edulis. Fish. Invest., Lond., Ser. 2, 24(1), 1-45. 


\section{Tables}

Table 1.

DEB parameters values used and determined for the growth model of $C$. gigas larvae, with symbols, units, values and references. * denotes parameters governing physiological rates based on experimental data at $25^{\circ} \mathrm{C}$.

\begin{tabular}{|c|c|c|c|c|}
\hline Parameters & Symbol & Units & Value & References \\
\hline \multicolumn{5}{|l|}{ Primary parameters } \\
\hline Maximum surface-area-specific ingestion rate & $\left\{\oiint_{m}\right\}$ & $\begin{array}{l}\mu \mathbf{m}^{3} \\
\mu \mathrm{m}^{-2}\end{array} \quad \mathrm{~d}^{-1}$ & 137 & This study * \\
\hline Half saturation coefficient & $X_{K}$ & $\mu \mathrm{m}^{3} \mu \mathbf{l}^{-1}$ & 600 & This study \\
\hline Assimilation efficiency & ae & - & 0.4 & $\begin{array}{l}\text { Walne (1965) } \\
\text { Sprung (1984) }\end{array}$ \\
\hline $\begin{array}{l}\text { Maximum surface-area-specific assimilation } \\
\text { rate }\end{array}$ & $\left\{\operatorname{sat}_{m}\right\}$ & $\mathrm{J} \mathrm{d}^{-1} \mathbf{c m}^{-2}$ & 25 & This study \\
\hline Arrhenius temperature & $T_{A}$ & $\mathbf{K}$ & 11000 & This study \\
\hline Volume-specific maintenance costs & {$[\& \&]$} & $\mathrm{J} \mathrm{d}^{-1} \mathbf{c m}^{-3}$ & 24 & Pouvreau et al. (2006) * \\
\hline Maximum energy density & {$\left[E_{m}\right]$} & $\mathrm{J} \mathbf{~ c m}^{-3}$ & 2295 & Pouvreau et al. (2006) \\
\hline Volume-specific costs for structural growth & {$\left[E_{G}\right]$} & $\mathrm{J} \mathbf{c m}^{-3}$ & 1900 & Pouvreau et al. (2006) \\
\hline $\begin{array}{l}\text { Fraction of spent on maintenance plus } \\
\text { growth }\end{array}$ & $\kappa$ & - & 0.45 & Pouvreau et al. (2006) \\
\hline Maintenance rate coefficient & 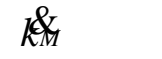 & d & 0.0126 & Pouvreau et al. (2006) \\
\hline Energy conductance & $\&$ & $\mathbf{c m ~ d}^{-1}$ & 0.183 & $\begin{array}{l}\text { van der Veer et al. (2006) } \\
*\end{array}$ \\
\hline Shape coefficient & $\delta_{M}$ & - & 0.658 & This study \\
\hline \multicolumn{5}{|l|}{ Additional parameters } \\
\hline Reference temperature & $T_{1}$ & $\mathbf{K}$ & 298 & This study \\
\hline Lower boundary of tolerance range & $T_{L}$ & $\mathbf{K}$ & 285 & Abdel-Hamid et al. (1992) \\
\hline Upper boundary of tolerance range & $T_{H}$ & $\mathbf{K}$ & 306 & This study \\
\hline Rate of decrease at lower boundary & $T_{A L}$ & $\mathbf{K}$ & 75000 & van der Veer et al. (2006) \\
\hline Rate of decrease at upper boundary & $T_{A H}$ & $\mathbf{K}$ & 75000 & van der Veer et al. (2006) \\
\hline Energy content of food & $\boldsymbol{\mu}_{X}$ & $\mathbf{J} \boldsymbol{\mu \mathbf { m } ^ { - 3 }}$ & $\underset{9}{4.5} \times 10^{-}$ & $\begin{array}{l}\text { Brown, (1991) } \\
\text { Brown and Robert, } \\
(2002)\end{array}$ \\
\hline Egg energy content & $\boldsymbol{E}_{0}$ & $\mathbf{J}$ & $6 \times 10^{-4}$ & This study \\
\hline Age at first feeding & $a_{b}$ & d & 5.5 & This study \\
\hline Length at metamorphosis & $L_{m t}$ & $\mu \mathrm{m}$ & 300 & This study \\
\hline
\end{tabular}


Table 2.

Comparison between experimental and simulated outputs for growth of $C$. gigas larvae under different temperatures $\left({ }^{\circ} \mathrm{C}\right)$, according to four parameters: coefficient of determination $\left(\mathrm{R}^{2}\right)$; slope of regression; residual standard deviation ( $\mathrm{rsd}$ ) and difference (d) between the mean of simulated and observed data.

\begin{tabular}{llllll}
\hline Parameters & 17 & 22 & 25 & 27 & 32 \\
\hline $\mathrm{R}^{2}$ & $\mathbf{0 . 9 8 7}$ & 0.972 & 0.996 & 0.984 & 0.977 \\
slope & $\mathbf{0 . 8 3 1}$ & 0.832 & 0.935 & 0.870 & 0.849 \\
rsd & 19.804 & 15.702 & 11.522 & 12.639 & 17.266 \\
d & 18.186 & 3.496 & 9.514 & -2.106 & 8.326 \\
\hline
\end{tabular}


Table 3.

Comparison between experimental and simulated outputs for growth of $C$. gigas larvae under different food density conditions $\left(\mu \mathrm{m}^{3} \mu^{l^{-1}}\right)$, according to four parameters: coefficient of determination $\left(R^{2}\right)$; slope of regression; residual standard deviation ( $\left.r s d\right)$ and difference (d) between the mean of simulated and observed data.

\begin{tabular}{lllllllll}
\hline Parameters & 70 & 280 & 450 & 960 & 1000 & 1900 & 2100 & 3300 \\
\hline$R^{2}$ & $\mathbf{0 . 9 5 4}$ & $\mathbf{0 . 6 1 1}$ & $\mathbf{0 . 9 8 7}$ & $\mathbf{0 . 9 8 3}$ & $\mathbf{0 . 9 7 4}$ & $\mathbf{0 . 9 6 1}$ & $\mathbf{0 . 9 8 7}$ & $\mathbf{0 . 9 9 0}$ \\
slope & $\mathbf{9 . 8 6 5}$ & $\mathbf{0 . 8 6 5}$ & $\mathbf{1 . 1 7 8}$ & $\mathbf{0 . 9 3 9}$ & $\mathbf{0 . 9 8 8}$ & $\mathbf{0 . 9 2 6}$ & $\mathbf{0 . 9 2 4}$ & $\mathbf{0 . 9 4 9}$ \\
rsd & 5.542 & 29.562 & 27.705 & $\mathbf{1 0 . 0 4 5}$ & $\mathbf{1 0 . 5 1 7}$ & $\mathbf{1 4 . 3 9 5}$ & $\mathbf{1 5 . 1 2 0}$ & 20.783 \\
$\mathrm{~d}$ & -3.488 & -25.601 & -25.707 & $-\mathbf{0 . 2 4 3}$ & -3.785 & 11.307 & 13.433 & $\mathbf{1 9 . 6 4 8}$ \\
\hline
\end{tabular}




\section{Table 4.}

Comparison between experimental and simulated outputs for growth of four "external" larval cultures of $C$. gigas larvae, according to four parameters: coefficient of determination $\left(\mathrm{R}^{2}\right)$; slope of regression; residual standard deviation (rsd) and difference (d) between the mean of simulated and observed data.

\begin{tabular}{lllll}
\hline Parameters & 1 & 2 & 3 & 4 \\
\hline$R^{2}$ & 0.996 & 0.999 & 0.993 & 0.998 \\
slope & 1.102 & 0.996 & 1.060 & 1.045 \\
rsd & 10.637 & 8.812 & 12.118 & 7.038 \\
d & 3.599 & 8.626 & 8.451 & 4.759 \\
\hline
\end{tabular}




\section{Figures}

Fig. 1.

Schematic representation of the energy flow through Crassostrea gigas larvae according to the DEB model (Kooijman, 2000). The three state variables are highlighted in grey.

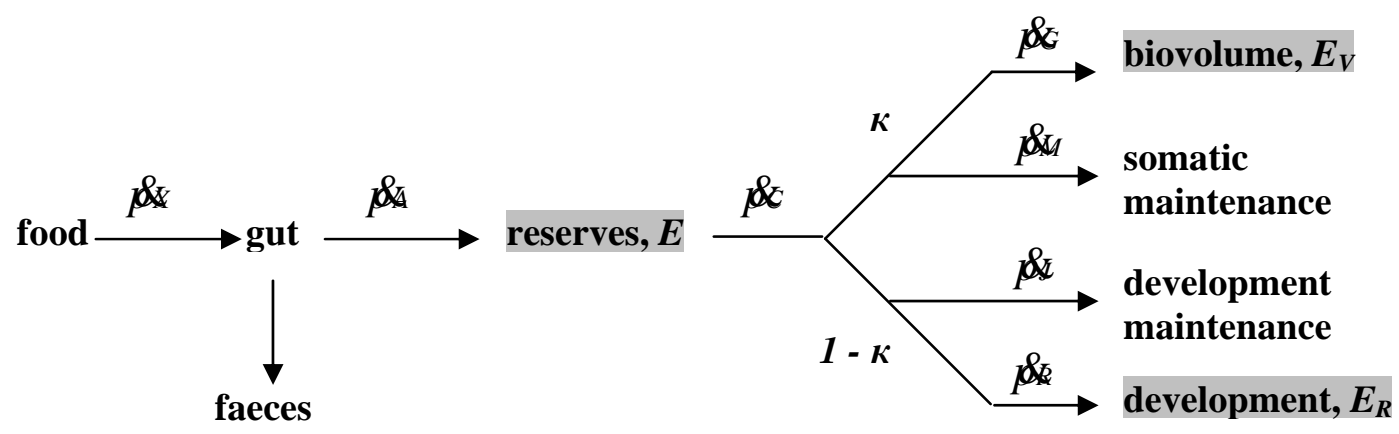


Fig. 2.

Shell length $(\mu \mathrm{m})$ and somatic wet mass (ng) relationship for $C$. gigas larvae reared at $25^{\circ} \mathrm{C}$. Shape coefficient value $0.658(n=77)$. Observed wet weights (dots) include structure and reserves; continuous curve (fitted according stochastic frontier analysis based on Battese \& Coelli, 1992) represents the "minimal envelope" between length, $L$, and structural body volume, $V$, without reserves.

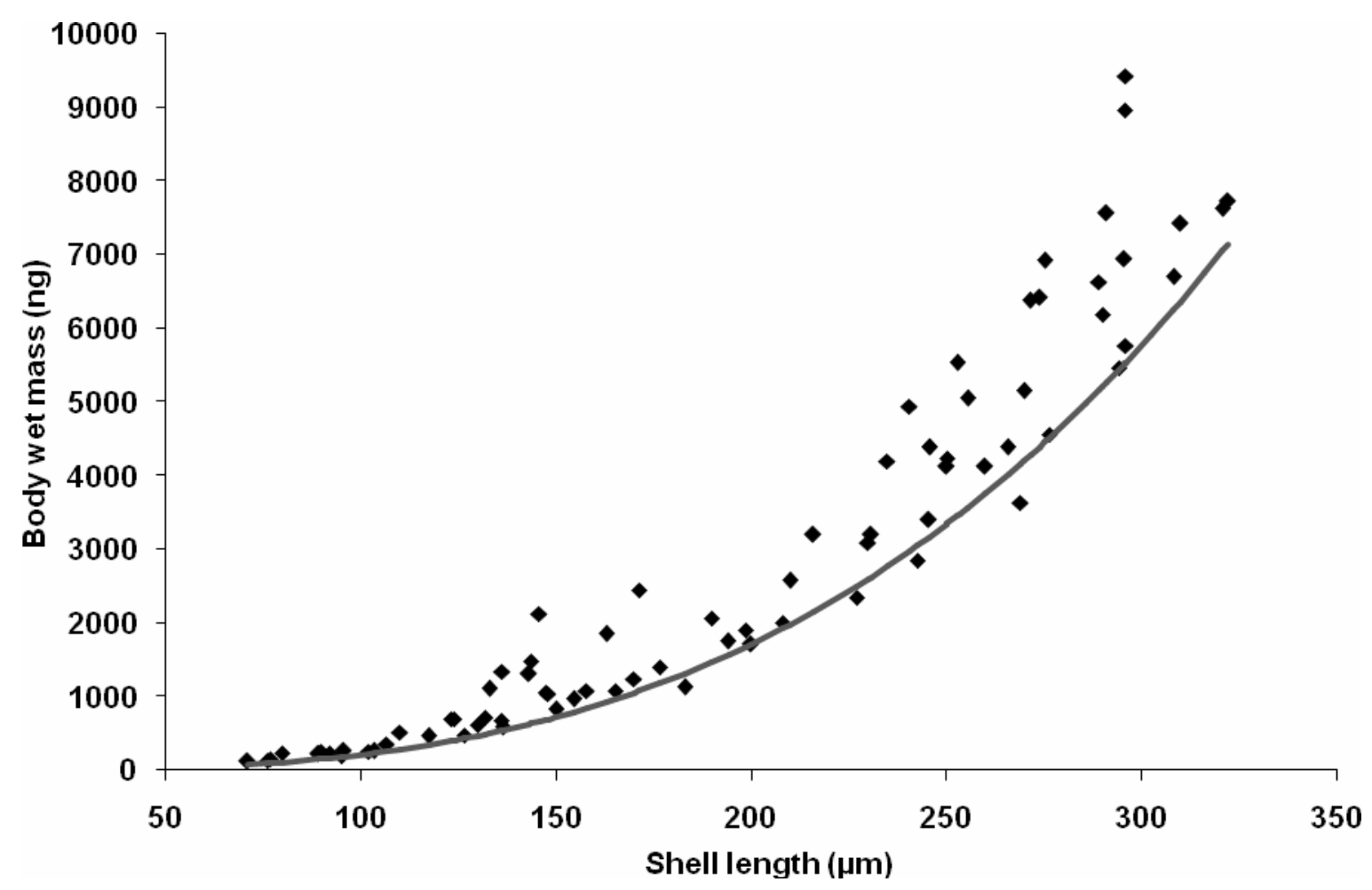


Fig. 3.

Effect of temperature on standardized growth rate of $C$. gigas larvae. The continuous curve shows the fitting of Eq. 11 to datasets; crosses represent datasets from literature (His et al., 1989) and circles represent our own experimental datasets.

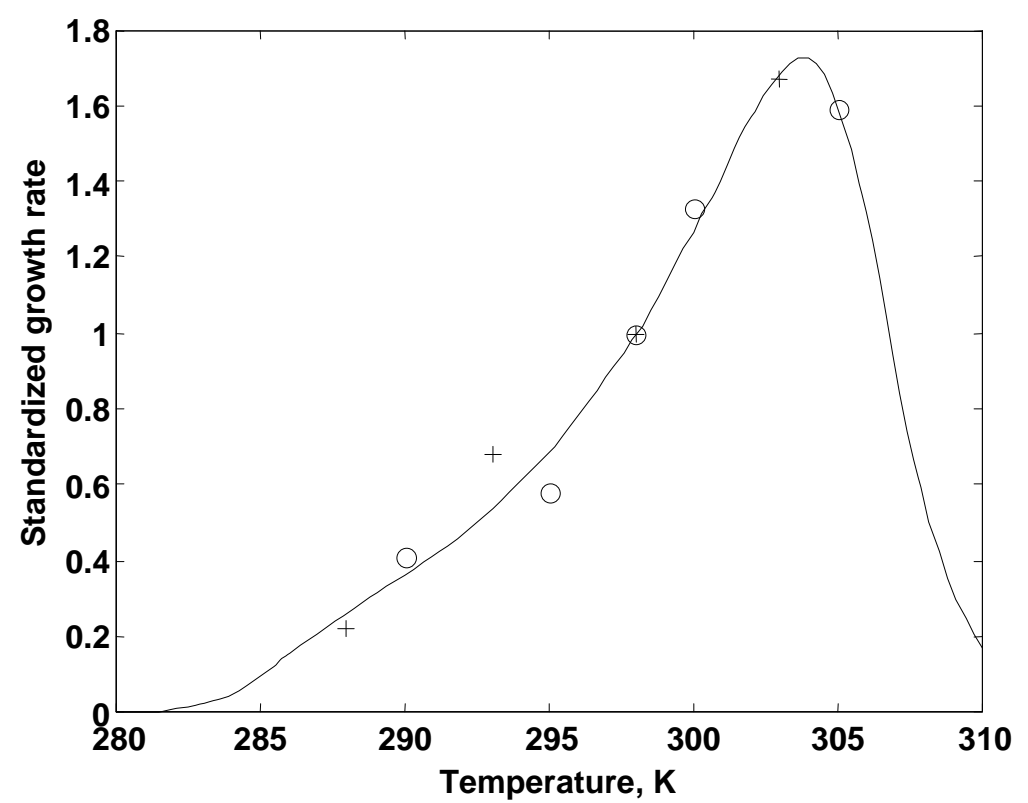


Fig. 4.

The ingestion rate, $\&$, of $C$. gigas larvae, reared at $25^{\circ} \mathrm{C}$, as a function of food density, $X$. The curve is a sigmoid (type 3 ) functional response where maximum ingestion rate $\left\{\&_{m}\right\}=$

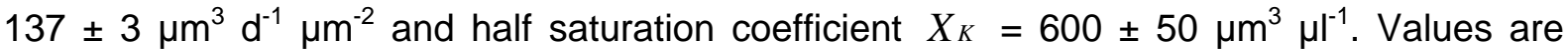
means $(n=10) \pm$ standard deviation.

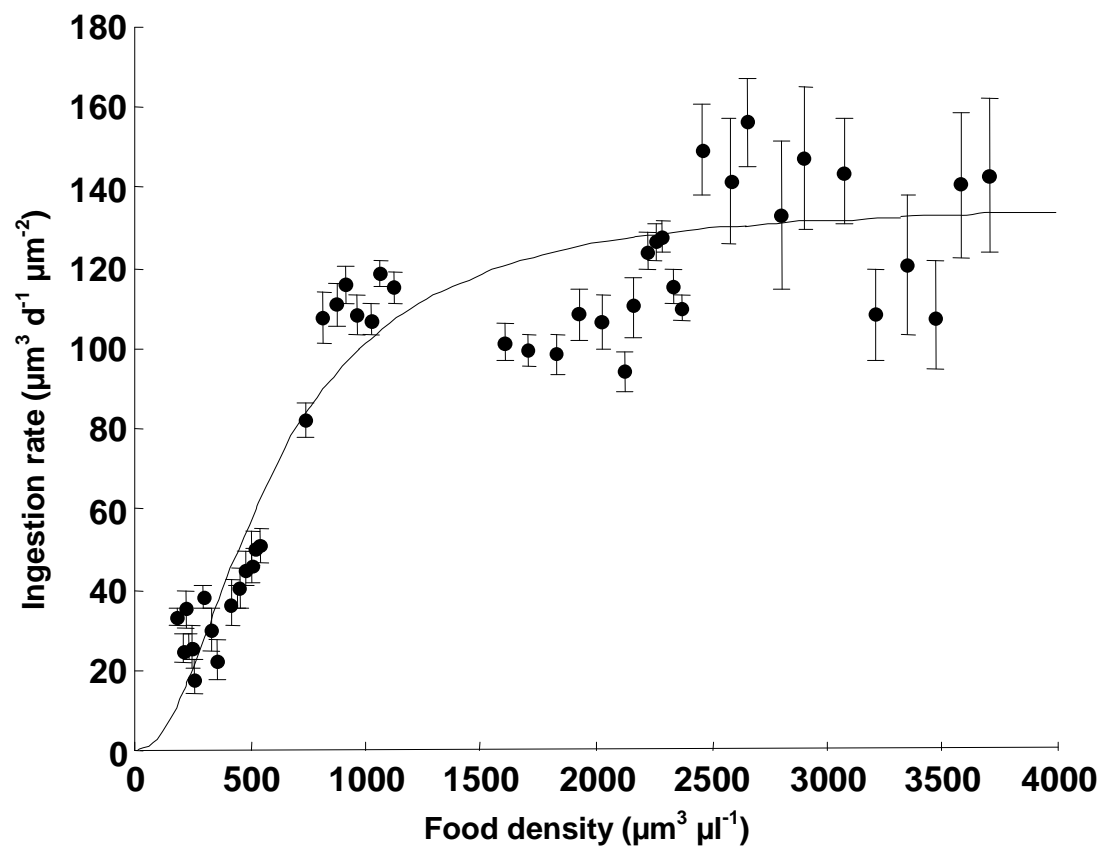


Fig. 5.

Simulated (solid line) and observed (points) growth for $C$. gigas larvae under different temperatures: 17 (a), 22 (b), 25 (c), 27 (d) and $32{ }^{\circ} \mathrm{C}$ (e). The other environmental conditions were optimal: $34 \mathrm{psu}$ and food density of $1400 \mu \mathrm{m}^{3} \mu^{-1}$. Mean observed values are presented with their standard deviation.

a)

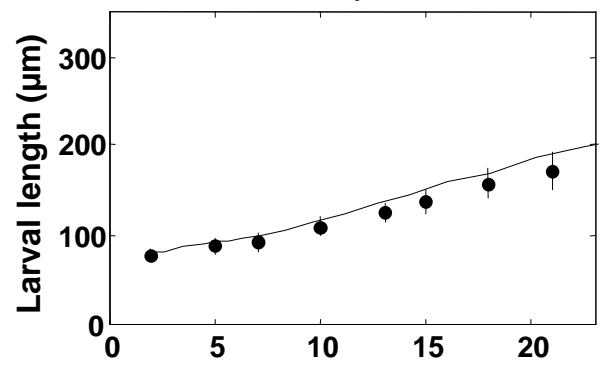

c)

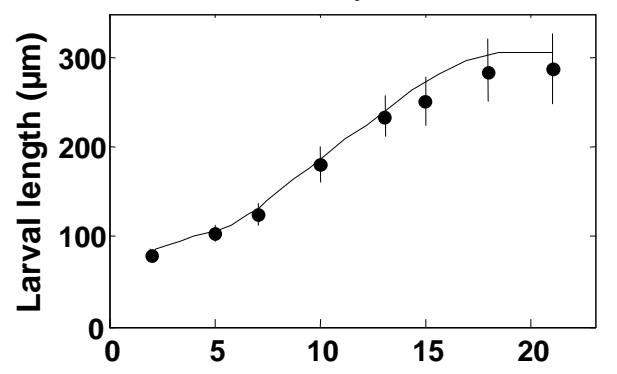

b)

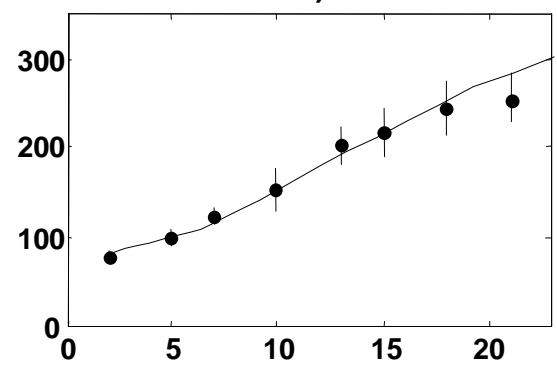

d)

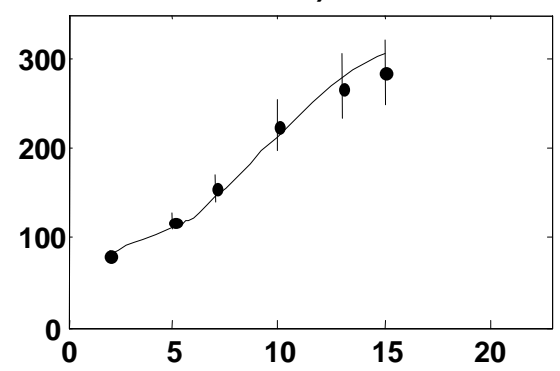

e)

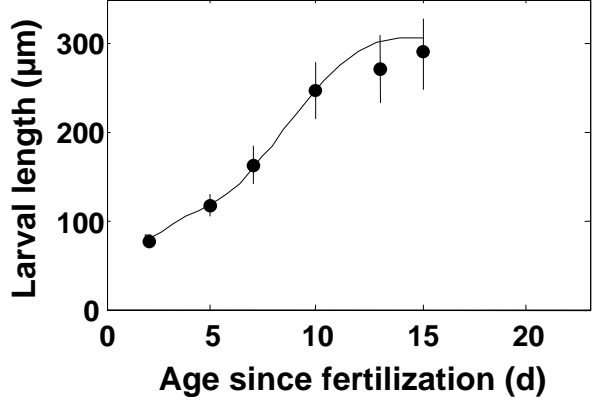


Fig. 6.

Simulated (solid line) and observed (points) growth for $C$. gigas larvae under different food density conditions: 70 (a), 280 (b), 450 (c), 960 (d), 1000 (e), 1900 (f), 2100 (g) and 3300 $\mu \mathrm{m}^{3} \mu \mathrm{l}^{-1}(\mathrm{~h})$. The other environmental conditions were optimal: $34 \mathrm{psu}$ and $25{ }^{\circ} \mathrm{C}$. Mean observed values are presented with their standard deviation.

a)

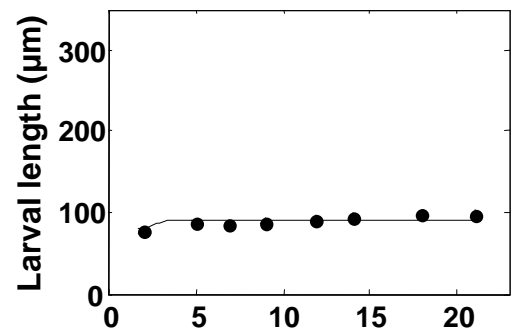

c)

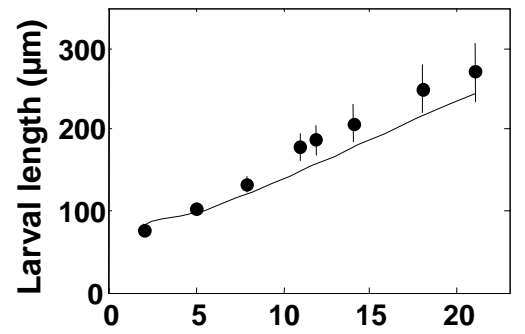

e)

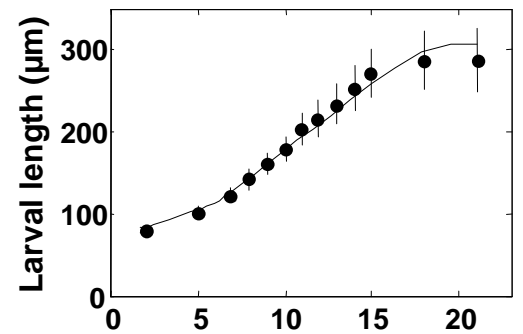

g)

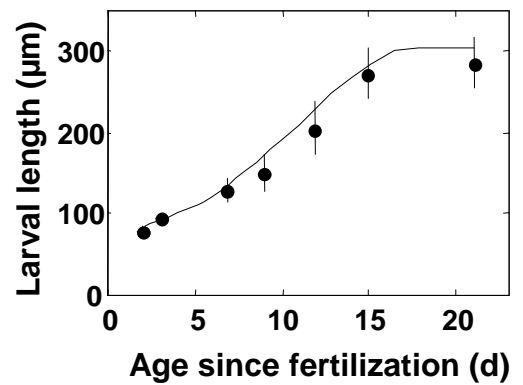

b)

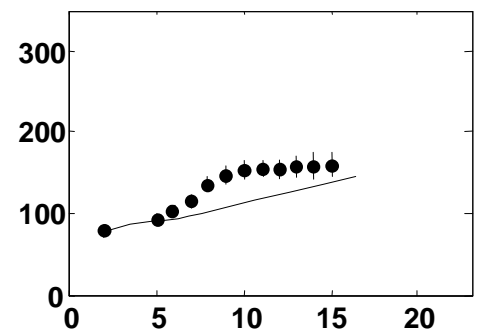

d)

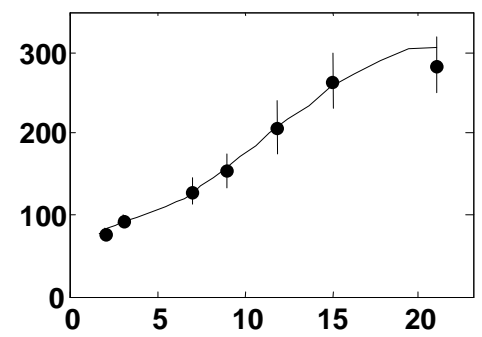

f)

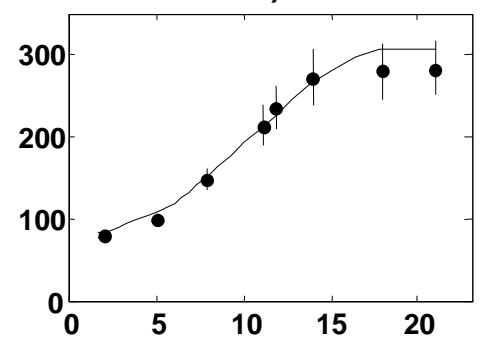

h)

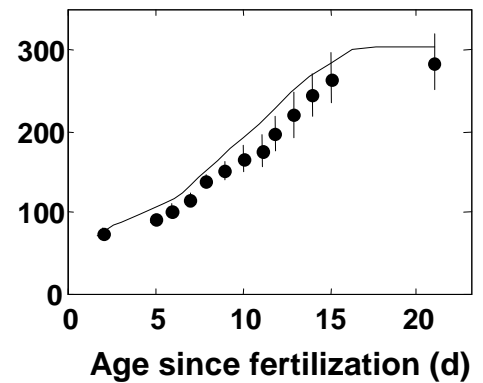


Fig. 7.

Simulated (solid line) and observed (points) growth for $C$. gigas larvae in a comparison with "external" rearing data. The environmental conditions were kept optimal: $34 \mathrm{psu}, 25^{\circ} \mathrm{C}$ and

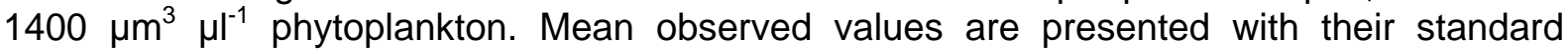
deviation.

a)

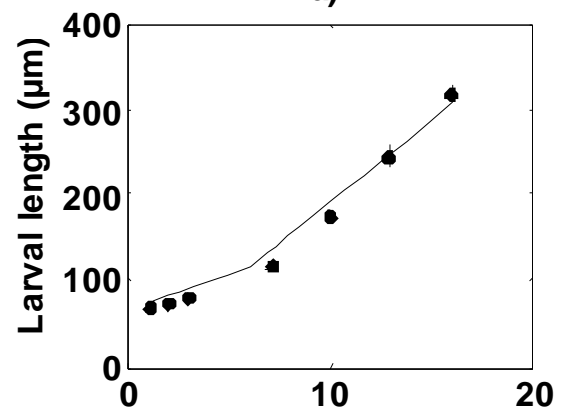

c)

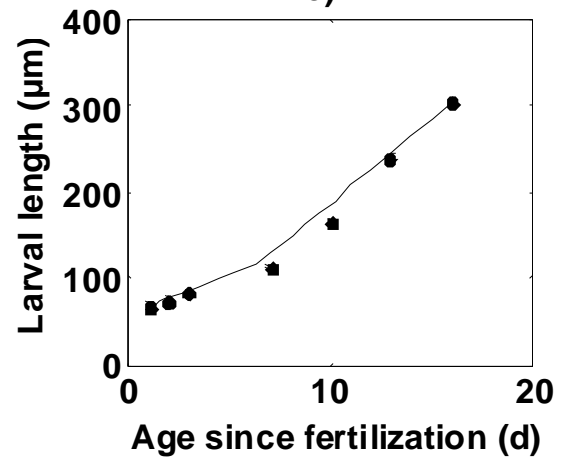

b)

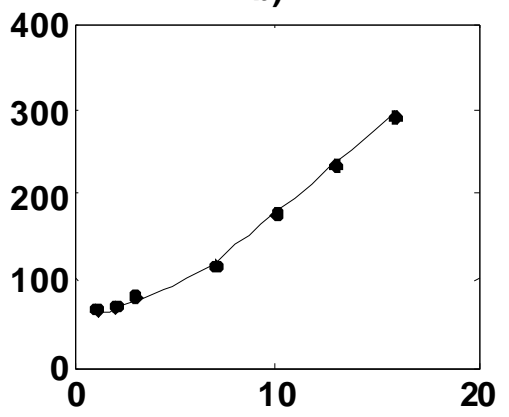

d)

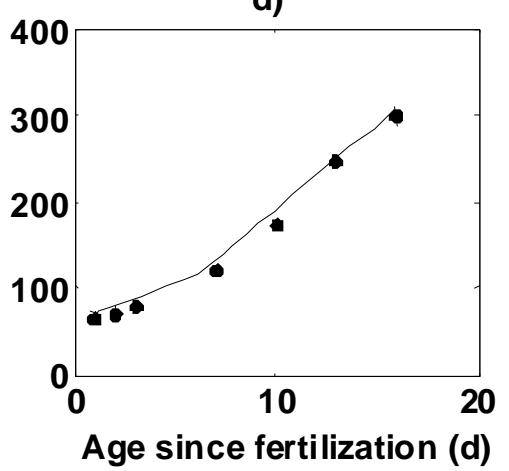

